\title{
Plastic Mulches Improved Plant Growth and Suppressed Weeds in Late Summer- planted Floricane-fruiting Raspberry
}

\author{
Huan Zhang and Carol Miles \\ Department of Horticulture, Washington State University, Northwestern \\ Washington Research \& Extension Center, Mount Vernon, WA 98273
}

Shuresh Ghimire
University of Connecticut, Tolland County Extension Center, Vernon, CT 06066

Chris Benedict

Washington State University, Whatcom County Extension, Bellingham, WA 98225

Inga Zasada

U.S. Department of Agriculture-Agricultural Research Service, Corvallis, OR 97330

Hang Liu

Department of Apparel, Merchandising, Design and Textiles, Washington State University, Pullman, WA 99164

\section{Lisa DeVetter \\ Department of Horticulture, Washington State University, Northwestern Washington Research \& Extension Center, Mount Vernon, WA 98273}

Additional index words. biodegradable plastic mulches, plasticulture, Rubus ideaus, summerbearing raspberry, tissue culture

\begin{abstract}
Planting floricane-fruiting red raspberry (Rubus ideaus L.) propagated through tissue culture (TC) is becoming increasingly popular in the Pacific Northwest. However, there is a challenge associated with their establishment compared with traditional planting materials (dormant roots and canes), especially regarding weed management due to their sensitivity to herbicides. In addition, there has been an increased interest in late summer planting compared with traditional spring planting because growers find improved establishment in late summer planting. Although polyethylene (PE) and biodegradable plastic mulches (BDMs) have demonstrated excellent weed control and increased plant growth and yield in spring-planted TC raspberry, their impacts in late summer plantings are still unknown. The overall objective of this study was to investigate whether PE mulch and BDMs have similar effects on weed management and raspberry growth and yield in late summer plantings as in spring plantings. One PE mulch, four BDMs (BASF 0.5, BASF 0.6, Novamont 0.5 , and Novamont 0.6 ), and a bare ground (BG) control were evaluated in a commercial 'WakeHaven' raspberry field planted in Aug. 2017. Mulch performance [percent soil exposure (PSE)], mulch mechanical properties (elongation and breaking force), soil temperature and moisture, plant growth, fruit yield and quality, and weed suppression were measured from 2017 to 2019. Average PSE was $1.4 \%$ and $2.0 \%$ to $15.0 \%$ by Dec. 2017 in the PE and BDM treatments, respectively. PE mulch generally had greater elongation and breaking force than BDMs. All BDMs were removed by Mar. 2018 because of the damage caused by on-farm activities and strong winds. Although average primocane height was greater for plants grown with PE mulch compared with all the other treatments except BASF 0.5 in Sept. 2018, there was no difference in yield between PE and the BG treatments, potentially because of cold damage on the buds in PE plots. There were no weeds in any of the mulched treatments in Sept. and Oct. 2017 and in PE mulch in Sept. 2018. In contrast, the BG plots had 51, 51, and 266 weeds $/ \mathrm{m}^{2}$, respectively, and required handweeding and herbicide applications. In addition, early season application of herbicides to suppress primocane emergence was not required in the $\mathrm{PE}$ plots. Overall, PE mulch could be a viable tool for growers planting raspberry in late summer. The suitability of BDMs with similar thicknesses and formulations as used in this experiment is uncertain for late summer plantings because of the damage caused by on-farm activities and strong winds.
\end{abstract}

The Pacific Northwest (PNW, composed of Washington and Oregon in the United States and British Columbia in Canada) is an important region for floricane-fruiting red raspberry (Rubus idaeus L.) production (DeVetter et al., 2020; USDA NASS, 2019).
Typically, growers plant bareroot canes or root cuttings in the spring, allow plants to establish the year of planting, and begin harvesting fruit from floricanes the next summer. Subsequent floricane production over future years allows the planting to produce fruit annually for the life of the planting.

Raspberry growers in the PNW have recently started to transition from using bareroot canes and root cuttings to TC transplants ( $\mathrm{P}$. Moore, personal communication). TC is a technique that allows nurseries to rapidly produce clean plants that are free from diseases, nematodes, insects, and viruses (TheilerHedtrich and Baumann, 1989). In addition, some desirable cultivars are available only as TC transplants, and many other raspberry cultivars are increasingly being offered as TC transplants (Peerbolt, 2020). However, TC transplants are more expensive than traditional forms of planting material. They also can be difficult to establish because they compete poorly with weeds, and the green foliage on TC transplants limits the use of post-plant herbicides. Poor planting establishment may ensue, resulting in a field that produces low yields and possibly with shorter planting longevity, which reduces on-farm profitability.

To promote the establishment and growth of TC transplants, some growers have started planting in late summer (August) because this planting time allows plants a longer period of time for establishment. In this system, TC transplants overwinter and grow primocanes during the first and second years, with first fruit production occurring $\approx 22$ months after planting. Late summer plantings also eliminate the challenges associated with spring planting, such as rain, saturated soils, and poor weather conditions that can delay planting. Although late summer planting systems are promising, weed management is still a challenge.

Plastic mulches, such as PE, have been used globally in agriculture since the 1960s, primarily in annual production systems, and provide the benefits of weed control, improved plant growth, modified soil temperature and moisture, and increased yields (Kasirajan and Ngouajio, 2012; Lamont, 2017; Miles et al., 2012). PE mulch use in perennial systems is limited, but has demonstrated benefits such as improved weed management and establishment in spring-planted TC raspberry (Trinka and Pritts, 1992; Zhang et al., 2019). However, PE mulch removal and disposal can be expensive and is estimated to cost up to $\$ 534 /$ ha in horticultural systems with a 2.4-m spacing between bed centers (Velandia et al., 2019). PE mulch also has waste management challenges (Kasirajan and Ngouajio, 2012). Mulch is seldom recycled because of contamination with residual soil and plant debris, high cost of transport, and limited availability of recycling facilities that can handle PE mulch waste (Grossman, 2019; Levitan and Barros, 2019). It is estimated that less than $10 \%$ of agricultural PE mulch in the United States is recycled, and most is landfilled, stockpiled, 
or burned (Goldberger et al., 2015; Kasirajan and Ngouajio, 2012; Levitan and Barros, 2019; Miles et al., 2017).

One potential alternative to PE mulch is BDM. BDMs are designed to biodegrade at least $90 \%$ into $\mathrm{CO}_{2}$, water, and microbial biomass through microbial activities within 2 years under ambient soil conditions or standardized laboratory testing conditions [American Society for Testing and Materials (ASTM) 5988-18, 2018; Brodhagen et al., 2015; European Norms (EN) 17033, 2018]. In the past decade, many studies have demonstrated that BDMs can provide benefits comparable to PE mulch in annual production systems in terms of weed management, soil temperature and moisture modification, and yield enhancement (Anzalone et al., 2010; Costa et al., 2014; DeVetter et al., 2017; Ghimire et al., 2018; Miles et al., 2012). Few studies have explored the use of BDMs in perennial production systems. Mulch requirements for perennial systems are different from those for annual systems because perennial crops typically require a longer mulching period. Furthermore, mulch incorporation via tillage cannot be done annually in perennial systems. Therefore, it is unknown whether BDMs designed for relatively short periods of use are suitable in perennial production systems like floricane-fruiting raspberry.

Trinka and Pritts (1992) found PE mulch suppressed weeds and provided improved soil moisture and temperature for primocanefruiting red raspberry in New York. In addition, Król-Dyrek and Siwek (2015) and Tecco et al. (2016) demonstrated that BDMs suppressed weeds and improved primocanefruiting raspberry yield. However, those studies were predominately focused on primocanefruiting raspberry, which differs physiologically and in its cultivation relative to floricane-fruiting raspberry (DeVetter et al., 2020). Although Zhang et al. (2019) found both $\mathrm{PE}$ mulch and BDMs provided weed control and increased yield of floricane-fruiting rasp-

Received for publication 19 Nov. 2019. Accepted for publication 6 Feb. 2020.

Published online 9 March 2020.

This work was funded by the Washington Red Raspberry Commission, Washington State Commission on Pesticide Registration, and Washington State Department of Agriculture Specialty Crop Block Grant program. This work was also supported by the U.S. Department of Agriculture National Institute of Food and Agriculture Hatch project 1014919. We thank Dan Martens of Novamont and Ruth Watts of BASF for donating the biodegradable mulches and technical advice. We also thank the on-farm cooperation and assistance of Kevin Berendsen, Adam Enfield, and Julie Enfield at Enfield Farms. Last but not least, we appreciate the technical assistance by Sean Watkinson, Edward Scheenstra, Weixin Gan, Nadia Bostan, Yixin Cai, and Qianwen Lu, and soil insights by Markus Flury.

L.D. is the corresponding author. E-mail: lisa. devetter@wsu.edu.

This is an open access article distributed under the CC BY-NC-ND license (https://creativecommons.org/ licenses/by-nc-nd/4.0/). berry compared with the standard grower practice of BG cultivation (herbicides plus handweeding), the mulches were removed after 10 months. In addition, all of the previously mentioned studies were conducted in a springplanted system in which growers expect mulch to stay in place for $\approx 6$ to 10 months. In contrast, growers expect the mulch to stay in place for 18 to 24 months during the establishment phase of summer-planted floricane-fruiting raspberry.

The objectives of the current study were to evaluate the deterioration of PE mulch and BDMs, mulch mechanical properties after agricultural weathering, and the impacts of PE mulch and BDMs on soil temperature and moisture, plant growth, yield, fruit quality, and weed suppression in a late summer planting of floricane-fruiting raspberry established as TC transplants. This study contributes knowledge regarding the feasibility and implications of using PE mulch and BDMs in late summer floricane-fruiting raspberry plantings established using TC transplants in the PNW, as well as general information about the use of PE mulch and BDMs in perennial fruit crops.

\section{Materials and Methods}

Experimental design. The study was conducted on a commercial farm in Whatcom County, WA (lat. $48^{\circ} 56^{\prime} \mathrm{N}$; long. $122^{\circ} 32^{\prime} \mathrm{W}$ ) from 2017 to 2019 . The soil type is a sandy loam, characterized as volcanic ash and loess over glacial outwash (USDA, 2019). Before the current study, the field had been planted with 'WakeField' raspberry, which was removed in 2016. The entire field was then seeded with a winter wheat (Triticum aestivum L.) cover crop in Sept. 2016 and bed fumigated [Telone C-35 (65\% 1,3-di-chloropropene and $35 \%$ chloropicrin); Dow Agrosciences, Indianapolis, IN] at $25 \mathrm{~L} \cdot \mathrm{ha}^{-1}$ by a commercial fumigation company (Trident Agriculture Products; Woodland, WA) in June 2017. Fertilizer $\left(11 \mathrm{~N}-52 \mathrm{P}-0 \mathrm{~K}\right.$; $\mathrm{P}$ provided as $\mathrm{P}_{2} \mathrm{O}_{5}$ ) was broadcast at a rate of $145 \mathrm{~kg} \cdot \mathrm{ha}^{-1}$ in June 2017 after fumigation. Raised bed dimensions were $0.4 \mathrm{~m}$ high and 0.7 and $1.0 \mathrm{~m}$ wide across the top and bottom, respectively, and were formed during the bed fumigation operation. The experimental design was a randomized complete block with six treatments replicated five times. The six treatments included one black PE mulch, four black BDMs, and a BG control that is industry standard practice (Table 1). The plots were spaced $3 \mathrm{~m}$ center-to-center, and each plot was $64 \mathrm{~m}$ long nested within a single row. The experimental area was $0.6 \mathrm{ha}(90 \mathrm{~m} \times 64 \mathrm{~m})$ and spanned 30 rows within a field of $\approx 150$ rows.

Mulch laying and field maintenance. Mulches were applied on 10 Aug. 2017 with a custom-built flatbed mulch layer (Corvallis, OR) modified by the authors (width and height extended) to enable mulch application over preformed fumigated raised beds. Mulch was applied over the drip tape (50$\mathrm{cm}$ emitter spacing and $0.67 \mathrm{~L}$ per $\mathrm{h}$ per $1-\mathrm{m}$ flow rate, Thinwall Dripline; TORO, Bloomington, $\mathrm{MN}$ ), which was placed slightly off center on the bed by the grower the same day as mulch laying. A custom-made dibble was used to create planting holes $(10 \mathrm{~cm}$ wide and $12.5 \mathrm{~cm}$ deep) immediately after mulch laying. Holes were $71 \mathrm{~cm}$ apart along the bed center. TC transplants of 'WakeHaven' grown in $40-\mathrm{cm}^{3}$ pots were hand planted on 29 Aug. 2017. A custom-blend liquid fertilizer (10 $\mathrm{kg} \cdot \mathrm{ha}^{-1} \mathrm{~N}, 11 \mathrm{~kg} \cdot \mathrm{ha}^{-1} \mathrm{P}, 10 \mathrm{~kg} \cdot \mathrm{ha}^{-1} \mathrm{~K}, 4 \mathrm{~kg} \cdot \mathrm{ha}^{-1}$ $\mathrm{Ca}$, and $4 \mathrm{~kg} \cdot \mathrm{ha}^{-1} \mathrm{Mg}$ ) was injected weekly through the single driptape from 25 Apr. to 27 June 2018. Plants in all treatments were irrigated and fertilized identically. The grower mechanically cultivated the alleyways of the field after mulch application, which inadvertently created many tears in the plastic mulches along the raised bed sides. From Oct. 2017 to Mar. 2018, 100 wind events with speeds of more than $36 \mathrm{~km} \cdot \mathrm{h}^{-1}$ [Washington State University (WSU) AgWeatherNet, 2019] enlarged and worsened the initial mulch damage caused by mechanical cultivation. As a result, BDM treatments in all replicates and PE mulch from the third replicate were removed by Mar. 2018 ( $\approx 8$ months after application). PE mulch in the other replicates was kept on the raised beds until Mar. $2019(\approx 20$ months after application), when the grower manually removed it.

Mulch deterioration. Mulch deterioration was visually assessed as PSE in the center 1$\mathrm{m}^{2}$ area in each plot twice per month (approximately the 15 th and 30th of each month) from Aug. 2017 to Mar. 2018. A rating of $0 \%$ represented a completely intact mulch, whereas a rating of $100 \%$ represented a plot with fully exposed soil. Ratings were made in $1 \%$ increments until $20 \%$ exposure and then $5 \%$ increments were used thereafter (Cowan et al., 2013).

Mulch mechanical properties. A single 1$\mathrm{m}^{2}$ section of mulch on the raised bed surface was collected from each plot in the first three replicates on 20 Jan. 2018 for assessment of mechanical properties. Mulches were cleaned by gently showering the surface with tap water to remove soil. After cleaning, all mulches were air-dried for $24 \mathrm{~h}$ before transporting to the Textiles Laboratory in Pullman, WA, for evaluation. Both elongation (measured by percentage elongation at break; \%) and breaking force (measured in Newton; N) were tested (Instron 5565A; Instron, Norwood, MA) following ASTM D5035-06 Standard Test Method for Breaking Force and Elongation of Textile Fabric (Strip Method) with the only exception that the samples were tested under ambient temperature of $25{ }^{\circ} \mathrm{C}$ rather than $21^{\circ} \mathrm{C}$ (ASTM, 2006). Each sample was tested by placing the two sample clamps $75 \mathrm{~mm}$ apart on-center. Six specimens measuring $2.5 \mathrm{~cm}$ wide and $15 \mathrm{~cm}$ long were randomly cut from each of the $1-\mathrm{m}^{2}$ samples with three specimens from the machine direction and three specimens from the transverse direction. A hydraulic press with a dye was used to cut the specimens.

Soil temperature and moisture. Soil temperature and moisture were measured (5 TM sensors; Meter Group, Inc., Pullman, WA) and recorded (EM50 Digital loggers; Meter Group, Inc.) every $15 \mathrm{~min}$ in all treatments in 
Table 1. Polyethylene (PE) and biodegradable plastic mulches (BASF and Novamont treatments) applied to tissue culture 'WakeHaven' raspberry in Aug. 2017 in northwestern Washington, 2017-19.

\begin{tabular}{lcll}
\hline Mulch product $^{\mathrm{z}}$ & Thickness $(\mu \mathrm{m})$ & \multicolumn{1}{c}{ Converter } & Key product ingredient(s) \\
\hline BASF 0.5 & 12.7 & PolyExpert Inc., Laval, Quebec, Canada & PLA + PBAT $^{\mathrm{y}}$ \\
BASF 0.6 & 15.2 & PolyExpert Inc., Laval, Quebec, Canada & PLA + PBAT \\
Novamont 0.5 & 12.7 & Dubois Agrinovation, Saint Remi, Quebec, Canada & Starch-based, PBAT copolyester \\
Novamont 0.6 & 15.2 & Dubois Agrinovation, Saint Remi, Quebec, Canada & Starch-based, PBAT copolyester \\
PE & 25.4 & FilmTech, LLC, Stanley, WI & Polyethylene \\
\hline
\end{tabular}

${ }^{\mathrm{z}} \mathrm{BASF}$ and Novamont are soil biodegradable products according to American Society for Testing and Materials D5988-18 and European Norms 17033 standards. ${ }^{\mathrm{y}} \mathrm{PLA}=$ polylactic acid; PBAT $=$ polybutylene adipate-co-terephthalate.

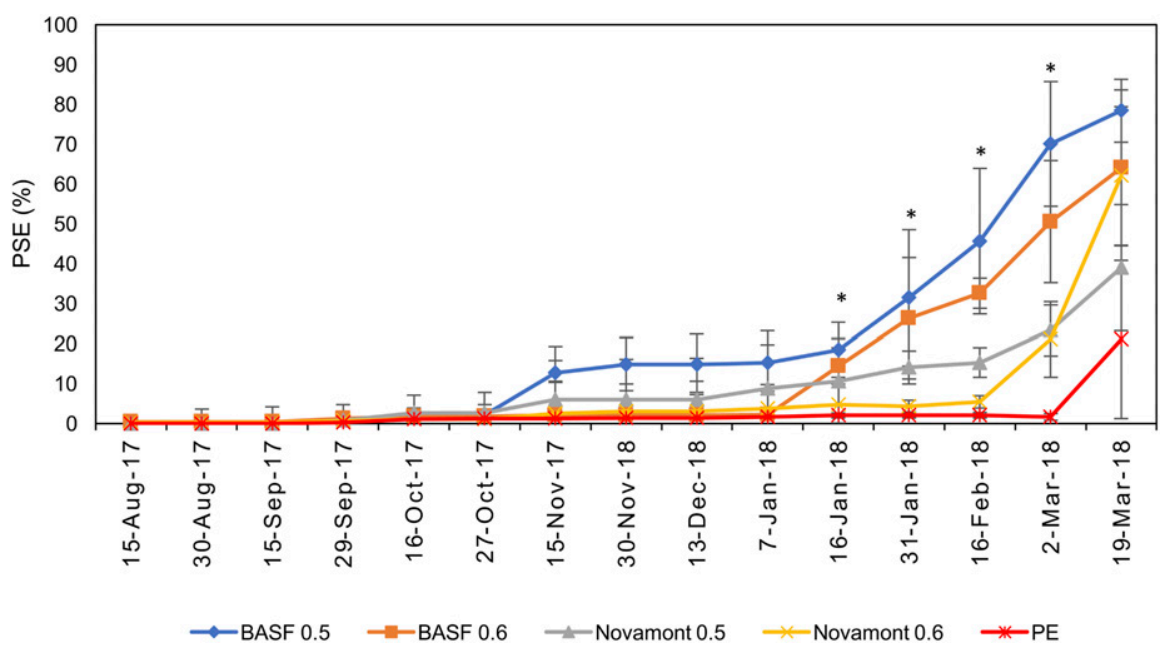

Fig. 1. Percent soil exposure (PSE; \%) of polyethylene (PE) and biodegradable plastic mulches (BASF and Novamont treatments, where $0.5=12.7 \mu \mathrm{m}$ and $0.6=15.2 \mu \mathrm{m})$ in 2017 and 2018 . *Significant difference at $P<0.05$, using a nonparametric Wilcoxon multiple comparisons test.

the third replicate from Aug. 2017 to Mar. 2018 for BDM treatments and from Aug. 2017 to Mar. 2019 for PE and BG treatments. Sensors were permanently installed in the center of each plot in the third replicate, $5 \mathrm{~cm}$ from the initial plant crown and $10 \mathrm{~cm}$ deep in the soil. The distance between the sensors and dripline emitters was kept at $10 \mathrm{~cm}$ and was consistent across all treatments. In Mar. 2018, loggers were retrieved from all BDM treatments because all of these mulches were removed due to damage. The sensor and logger in the PE mulch treatment were moved to the second replicate because ripped PE mulch in the third replicate was removed as well. The sensor in the PE plot was intentionally removed from Oct. 2017 to Jan. 2018 to protect sensors from pruning and canetying activities, whereas the sensor in the BG plot was buried in the soil to protect it during this period.

Cumulative plant growth. Plant growth was measured as primocane height and number from the same 10 permanent plants per plot from Aug. to Oct. 2017 and May to Sept. 2018, except for the plants in the BDM treatments from June to Aug. 2018 as mulch had been removed. However, final primocane height and number data were collected from all treatments in Sept. 2018. Primocane height was measured from the base of the crown to the tallest leaf tip from Aug. to Oct. 2017 and May to Sept. 2018, and primocane number per plant was measured by counting the number of primocanes that were more than $30 \mathrm{~cm}$ tall from June to Sept. 2018 (Zhang et al., 2019). Primocane emergence was determined in July 2019 from a 10-m region in the center of each plot by counting all primocanes emerging beyond the crown area, including those that were chemically removed through "primocane burning" by growers (DeVetter et al., 2020; Zhang et al., 2019). Primocane height and number were determined again in Sept. 2019 from the same 10 plants in the PE and BG treatments.

Fruit yield. Yield was determined from a permanent 18-m-long region within each from PE mulch and BG plots from 28 June to 6 Aug. 2019. No yield data were collected from BDM-treated plots because the treatments were removed by Mar. 2018 due to machine and wind damage. Furthermore, analysis of primocane growth data showed no differences among the BDM treatments compared with the BG treatment in Sept. 2018.

Average berry mass and fruit quality. Thirty ripe berries were randomly collected from each PE mulch and BG plot on 29 June, 16 July, and 6 Aug. 2019 and frozen at $-10^{\circ} \mathrm{C}$ after determination of average berry mass. These measurement times correspond to early, mid, and late harvest. Berry quality [soluble solids concentration ( $\mathrm{SSC}$ ), $\mathrm{pH}$, and titratable acidity (TA)] was measured from frozen samples. On 29 Aug. 2019, berries were thawed at room temperature $\left(22^{\circ} \mathrm{C}\right)$ for $4 \mathrm{~h}$ and then fruit from each treatment plot and time point were crushed in a sample mesh bag (Agdia, Inc., Elkhart, IN) before the juice plot. Fruit were machine harvested 15 times was strained into a test tube. SSC (\%) of the juice was measured as ${ }^{\circ}$ Brix using a digital refractometer (HI-96801; Hanna Instruments, Woonsocket, RI). Initial juice $\mathrm{pH}$ and TA were determined simultaneously using a digital titrator (HI-84532; Hanna Instruments) that titrated to an endpoint of $\mathrm{pH} 8.1$ using a solution of $0.1 \mathrm{~N}$ sodium hydroxide. Juice from each treatment plot and time point were analyzed three times for SSC, pH, and TA, and the means of the three values were calculated.

Weed suppression. Total number of weeds and dry shoot biomass within a $1-\mathrm{m}^{2}$ area adjacent to the south side of the PSE region were determined monthly from Aug. to Oct. 2017 and May to Sept. 2018 and 2019. However, weed data were not recorded in the BDM treatments in 2018 and 2019 due to mulch removal. Weeds were counted, clipped at the soil surface, and dried at $38{ }^{\circ} \mathrm{C}$ for $5 \mathrm{~d}$, and then dry shoot biomass was recorded.

Statistical analyses. All data were analyzed with JMP14.0.0 (SAS Institute, Cary, NC). Data were evaluated for assumptions of normality and homogeneity of variance before using analysis of variance (ANOVA). Mulch mechanical properties (i.e., elongation and breaking force in the machine and transverse directions), primocane height from Sept. 2017 to Aug. 2018 and in Sept. 2019, primocane number, fruit yield, average berry mass, and fruit quality variables were analyzed as a randomized complete block design using ANOVA. Mean separations were performed with Tukey's honestly significant difference test with $\alpha=0.05$. Mulch deterioration (i.e., PSE), primocane height in Aug. 2017 and Sept. 2018, and monthly number of weeds and dry shoot biomass were analyzed using a Wilcoxon nonparametric test, and mean separations were performed with a Wilcoxon nonparametric multiple comparison procedure because these data did not meet the assumptions for ANOVA. Original means are presented.

\section{Results}

Mulch deterioration. PSE differed among treatments on 16 and 31 Jan., 16 Feb., and 2 Mar. $2018(P=0.04,0.03,0.02$, and 0.01 , respectively), where all BDM treatments had higher PSE than PE mulch (Fig. 1). The average PSE across all BDM treatments was only $2 \%$ on 27 Oct. 2017 but increased to $61 \%$ on 19 Mar. 2018. PE mulch maintained a low PSE (2\%) until 2 Mar. 2019, but it increased to $21 \%$ on 19 Mar. 2019. 
Table 2. Elongation (\%) and breaking force $(\mathrm{N})$ in the machine and transverse directions for polyethylene (PE) and biodegradable plastic mulches (BASF and Novamont treatments, where $0.5=12.7 \mu \mathrm{m}$ and $0.6=15.2 \mu \mathrm{m}$ ) collected $20 \mathrm{Jan}$. 2018; all mulches were applied in a raspberry field in Aug. 2017.

\begin{tabular}{lcccc}
\hline & \multicolumn{3}{c}{ Mulch mechanical properties } \\
\cline { 2 - 5 } Treatment & \multicolumn{2}{c}{ Machine direction } & Transverse direction \\
\hline BASF 0.5 & Elongation (\%) & Breaking force $(\mathrm{N})$ & $22.6 \mathrm{~b}$ & \\
BASF 0.6 & $26.2 \mathrm{c}$ & $6.2 \mathrm{bc}$ & $31.4 \mathrm{~b}$ & Breaking force $(\mathrm{N})$ \\
Novamont 0.5 & $35.9 \mathrm{bc}$ & $7.5 \mathrm{ab}$ & $37.1 \mathrm{~b}$ & $4.4 \mathrm{ab}$ \\
Novamont 0.6 & $53.6 \mathrm{~b}$ & $5.2 \mathrm{c}$ & $70.6 \mathrm{~b}$ & $3.8 \mathrm{ab}$ \\
PE & $218.1 \mathrm{a}$ & $6.5 \mathrm{bc}$ & $332.6 \mathrm{a}$ & $5.3 \mathrm{ab}$ \\
$P$ value & $<0.0001$ & $7.8 \mathrm{a}$ & 0.002 & $6.3 \mathrm{a}$ \\
\hline
\end{tabular}

${ }^{\mathrm{z}}$ Means followed by the same letter within a column are not significantly different at $P<0.05$ using a means comparison with a Tukey's honestly significant difference test for all dates.

Table 3. Average monthly soil temperature $\left({ }^{\circ} \mathrm{C}\right)$ from Aug. 2017 to Mar. 2019 in 'WakeHaven' raspberry grown with polyethylene (PE) and biodegradable plastic mulches (BASF and Novamont treatments, where $0.5=12.7 \mu \mathrm{m}$ and $0.6=15.2 \mu \mathrm{m}$ ) compared with bare ground (BG). Sensors were installed at a depth of 10 $\mathrm{cm}$ in the third replicate of each treatment, recorded every $15 \mathrm{~min}$, and data were averaged by month.

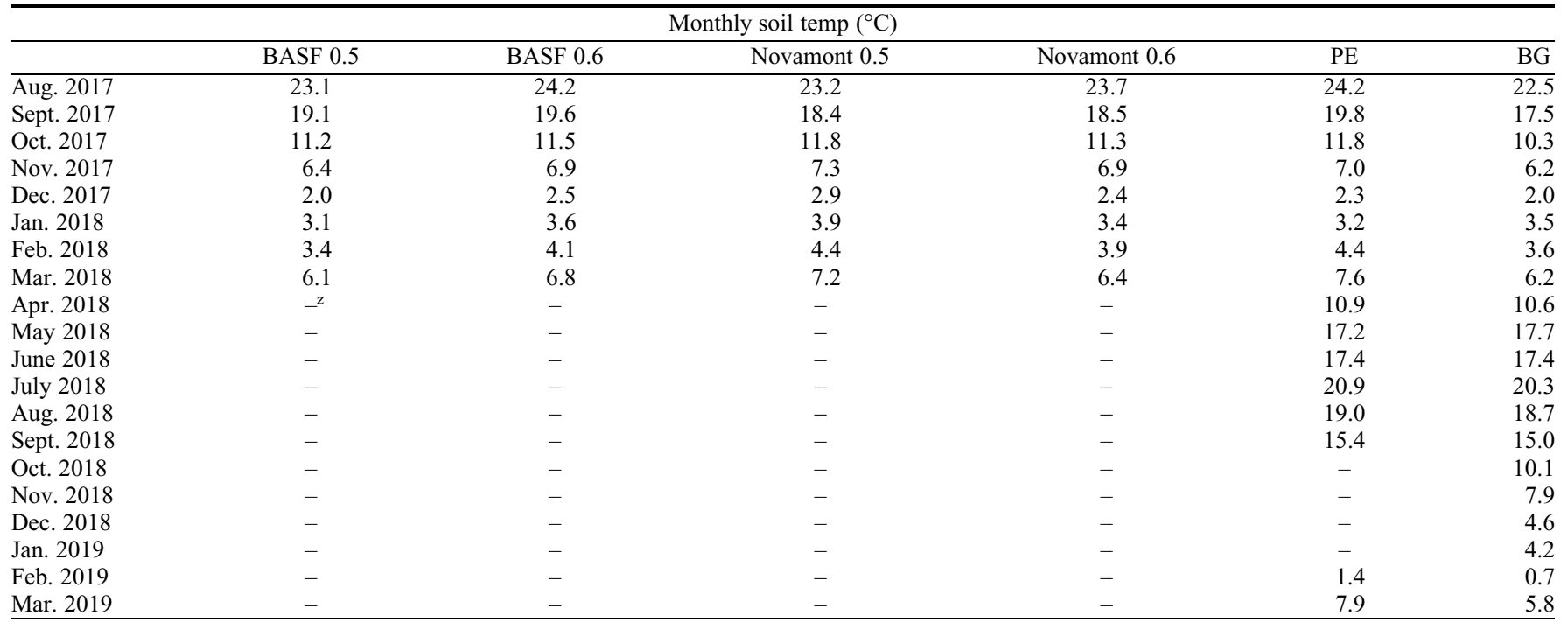

${ }^{\mathrm{z}}$ Soil temperature data for BASF and Novamont treatments after Mar. 2018 were not available, as biodegradable plastic mulches were removed in Mar. 2018; the sensor in the PE plot was intentionally removed from Oct. 2017 to Jan. 2018 to protect the sensor from pruning and cane-tying activities.

Mulch mechanical properties assessment. Elongation and breaking forces in machine and transverse directions differed for each treatment and among treatments (Table 2). In general, machine direction had lower elongation and higher breaking force than the transverse direction. In the machine direction, PE mulch had the highest elongation (218.1\%), whereas BASF $0.5(19.2 \%)$ and BASF $0.6(26.9 \%)$ had the lowest elongation; the remaining treatments were intermediate (44.8\% on average) $(P<0.0001)$. Breaking force in the machine direction was highest for PE mulch $(7.8 \mathrm{~N})$, which was similar to BASF $0.6(7.5 \mathrm{~N})$, and lowest for Novamont 0.5 $(5.2 \mathrm{~N})(P=0.0008)$. In the transverse direction, elongation was highest for PE mulch $(332.6 \%)$, but was the same across all other mulch treatments (on average 40.4\%) $(P=$ $0.002)$. Breaking force in the transverse direction was highest for PE mulch $(6.3 \mathrm{~N})$, which was similar to BASF 0.5 , BASF 0.6 , and Novamont 0.6 (average $4.8 \mathrm{~N}$ ), and was lowest for Novamont $0.5(3.8 \mathrm{~N})(P=0.02)$.

Soil temperature and moisture. Soil temperature under mulched treatments was usually numerically higher than the BG control (Table 3; data exclude all BDM treatments after Mar. 2018 due to BDM removal; data from the PE mulch treatment are not presented from Oct. 2018 to Jan. 2019 because of sensor removal). Before BDM removal (Mar. 2018), the average soil temperature across all mulched treatments was $18.1^{\circ} \mathrm{C}$ (range was 17.8 to $18.6{ }^{\circ} \mathrm{C}$ ), which was $1.3{ }^{\circ} \mathrm{C}$ higher than the BG control. From mulch application to PE mulch removal by the grower (Mar. 2019), soil temperature under PE mulch was $1.6^{\circ} \mathrm{C}$ greater than the BG control. Soil volumetric water content followed a similar trend as soil temperature from Aug. 2017 to Mar. 2018, where the average soil volumetric water content in all mulched treatments was $0.22 \mathrm{~m}^{3} / \mathrm{m}^{3}$ whereas it was $0.18 \mathrm{~m}^{3} / \mathrm{m}^{3}$ in the BG control (Table 4; data exclude all BDM treatments after Mar. 2018 because of BDM removal; data from the $\mathrm{PE}$ mulch treatment are not presented from Oct. 2018 to Jan. 2019 because of sensor removal). From Aug. 2017 to Mar. 2019, the average soil volumetric water content was $0.20 \mathrm{~m}^{3} / \mathrm{m}^{3}$ in the BG control and $0.19 \mathrm{~m}^{3} / \mathrm{m}^{3}$ for PE mulch.

Primocane height and number. Baseline plant height measured in Aug. 2017 did not differ among treatments $(P=0.20$; Table 5$)$. A month after transplanting, plants grown under all mulched treatments were $27 \mathrm{~cm}$ tall, which was $4 \mathrm{~cm}$ numerically greater than the $\mathrm{BG}$ control $(P=0.16)$. Although plants grown with mulches were always numerically taller than the BG control, there were no statistical differences between treatments until Aug. 2018, when plants grown with PE mulch were on average $15 \mathrm{~cm}$ taller than plants grown in the BG control $(P=0.04)$. In Sept. 2018, plants grown with $P E$ mulch had the greatest primocane height compared with all other treatments except BASF 0.5 , which was similar to the PE mulch treatment $(P=0.01)$. There were no differences in primocane number per plant among treatments during the entire study period (data not shown). Average primocane numbers in June, July, Aug., and Sept. 2018 were 16.5, 18, 19, and 20 per plant across all treatments, respectively $(P=0.61$, $0.56,0.79$, and 0.83 , respectively). Primocane emergence measured in July 2019 was significantly lower in the PE mulch treatment (6.1 primocanes $/ \mathrm{m})$ than the BG control $(10.7$ primocanes $/ \mathrm{m})(P=0.007)$, whereas primocane emergence was not measured in BDM plots because of early removal of BDMs. In Sept. 2019, there were no differences in primocane height and number per plant between PE mulch $(344 \mathrm{~cm}$ and seven primocanes, respectively) and the $\mathrm{BG}$ control $(343 \mathrm{~cm}$ and seven primocanes, respectively) $(P=0.80$ and 0.52 , respectively). 
Table 4. Average monthly soil volumetric water content $\left(\mathrm{m}^{3} / \mathrm{m}^{3}\right)$ from Aug. 2017 to Mar. 2019 in 'WakeHaven' raspberry grown with polyethylene (PE) and biodegradable plastic mulches (BASF and Novamont treatments, where $0.5=12.7 \mu \mathrm{m}$ and $0.6=15.2 \mu \mathrm{m}$ ) compared with bare ground (BG). Sensors were installed at a depth of $10 \mathrm{~cm}$ in the third replicate of each treatment, recorded data every 15 min, and data were averaged by month.

\begin{tabular}{|c|c|c|c|c|c|c|}
\hline \multicolumn{7}{|c|}{ Monthly soil volumetric water content $\left(\mathrm{m}^{3} / \mathrm{m}^{3}\right)$} \\
\hline & BASF 0.5 & BASF 0.6 & Novamont 0.5 & Novamont 0.6 & $\mathrm{PE}$ & $\overline{\mathrm{BG}}$ \\
\hline Aug. 2017 & 0.17 & 0.14 & 0.16 & 0.15 & 0.14 & 0.13 \\
\hline Sept. 2017 & 0.26 & 0.19 & 0.33 & 0.27 & 0.23 & 0.19 \\
\hline Oct. 2017 & 0.24 & 0.20 & 0.30 & 0.25 & 0.20 & 0.21 \\
\hline Nov. 2017 & 0.27 & 0.23 & 0.32 & 0.27 & 0.20 & 0.26 \\
\hline Dec. 2017 & 0.27 & 0.23 & 0.33 & 0.27 & 0.20 & 0.25 \\
\hline Jan. 2018 & 0.29 & 0.25 & 0.34 & 0.30 & 0.22 & 0.27 \\
\hline Feb. 2018 & 0.29 & 0.24 & 0.34 & 0.29 & 0.24 & 0.25 \\
\hline Mar. 2018 & 0.28 & 0.22 & 0.35 & 0.29 & 0.22 & 0.24 \\
\hline Apr. 2018 & ${ }^{\mathrm{z}}$ & - & - & - & 0.24 & 0.24 \\
\hline May 2018 & - & - & - & - & 0.18 & 0.18 \\
\hline June 2018 & - & - & - & - & 0.14 & 0.20 \\
\hline July 2018 & - & - & - & - & 0.11 & 0.14 \\
\hline Aug. 2018 & - & - & - & - & 0.15 & 0.15 \\
\hline Sept. 2018 & - & - & - & - & 0.11 & 0.13 \\
\hline Oct. 2018 & - & - & - & - & - & 0.13 \\
\hline Nov. 2018 & - & - & - & - & - & 0.22 \\
\hline Dec. 2018 & - & - & - & - & - & 0.25 \\
\hline Jan. 2019 & - & - & - & - & - & 0.26 \\
\hline Feb. 2019 & - & - & - & - & 0.21 & 0.18 \\
\hline Mar. 2019 & - & - & - & - & 0.21 & 0.22 \\
\hline
\end{tabular}

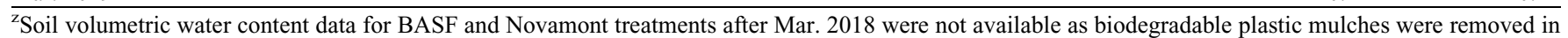
Mar. 2018; the sensor in the PE plot was intentionally removed from Oct. 2017 to Jan. 2018 to protect sensor from pruning and cane-tying activities.

Table 5. Average monthly primocane height from Aug. to Oct. 2017, Apr. to Sept. 2018, and Sept. 2019 in 'WakeHaven' raspberry grown with polyethylene (PE) and biodegradable plastic mulches (BASF and Novamont treatments, where $0.5=12.7 \mu \mathrm{m}$ and $0.6=15.2 \mu \mathrm{m}$ ) compared with bare ground (BG).

\begin{tabular}{|c|c|c|c|c|c|c|c|c|c|c|}
\hline \multicolumn{11}{|c|}{ Primocane ht $(\mathrm{cm})$} \\
\hline Treatment & Aug. 2017 & Sept. 2017 & Oct. 2017 & Apr. 2018 & May 2018 & June 2018 & July 2018 & Aug. 2018 & Sept. 2018 & Sept. 2019 \\
\hline$\overline{\text { BASF } 0.5}$ & 24 & 27 & 28 & 33 & 74 & $-^{z}$ & - & - & $272 \mathrm{ab}$ & - \\
\hline BASF 0.6 & 23 & 27 & 27 & 35 & 73 & - & - & - & $265 \mathrm{~b}$ & - \\
\hline Novamont 0.5 & 23 & 27 & 27 & 35 & 74 & - & - & - & $263 \mathrm{~b}$ & - \\
\hline Novamont 0.6 & 22 & 27 & 28 & 35 & 73 & - & - & - & $264 \mathrm{~b}$ & - \\
\hline PE & 23 & 27 & 29 & 36 & 74 & 133 & 178 & $242 \mathrm{a}^{\mathrm{y}}$ & $283 \mathrm{a}$ & 344 \\
\hline BG & 20 & 23 & 26 & 32 & 69 & 126 & 165 & $227 \mathrm{~b}$ & $267 \mathrm{~b}$ & 343 \\
\hline$P$ value & 0.20 & 0.16 & 0.55 & 0.27 & 0.78 & 0.21 & 0.06 & 0.04 & 0.01 & 0.80 \\
\hline
\end{tabular}

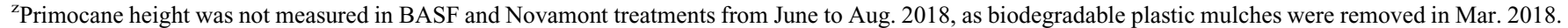

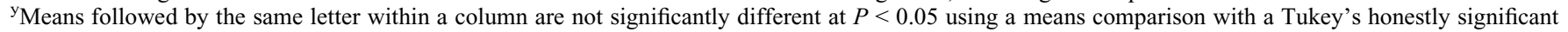
difference test for all dates, except Sept. 2018, which was analyzed using a nonparametric Wilcoxon multiple comparisons test.

Fruit yield. There was no difference in total fruit yield in 2019 between PE mulch and the $\mathrm{BG}$ control $(P=0.37$; Table 6$)$. Total raspberry yield averaged across plots collected from 15 harvests was $110.3 \mathrm{~kg} / 18 \mathrm{~m}$ for PE mulch and $117.5 \mathrm{~kg} / 18 \mathrm{~m}$ for the BG control. Plants grown in the BG control had a higher yield compared with plants grown with PE mulch in the first harvest $(P=0.03)$, whereas plants treated with $P E$ mulch had a higher yield than plants treated with the $\mathrm{BG}$ control during the sixth harvest $(P=0.03)$. No other yield differences were observed on individual harvest dates.

Average berry mass and fruit quality. Average berry mass measured at early, mid, and late harvest time points did not differ between treatments and averaged 5.4, 5.7, and $3.6 \mathrm{~g}$, respectively $(P=0.25,0.06$, and 0.81 , respectively). SSC, $\mathrm{pH}$, and TA did not differ among treatments within each sampling date except for the SSC of fruit harvested at the midseason sampling point (data not shown), when fruit from plants grown with PE mulch had a higher SSC (8.8\%) than the BG control $(8.1 \%)(P=0.03)$. The overall average $\mathrm{pH}$ and TA across treatments were $3.1 \%$ and $1.6 \%$, respectively. There was a harvest time effect for SSC within each treatment. The SSC of fruit was highest during the late sampling point (11.6\%), intermediate during the early sampling point $(10.2 \%)$, and lowest during the midsampling point $(8.5 \%)$ for both PE mulch $(P=0.03)$ and the BG control $(P=0.0003)$.

Weed suppression. Monthly number of weeds was typically higher in the BG control than mulched treatments (data not shown and data exclude all BDM treatments after June 2018 because of BDM removal). In Sept. and Oct. 2017, the number of weeds in the BG control was 51 weeds $/ \mathrm{m}^{2}$, but there were no weeds in any mulched plots $(P=0.01$ for both dates). Weed dry shoot biomasses for the same sampling times were $6.4 \mathrm{~g} / \mathrm{m}^{2}$ and 3.4 $\mathrm{g} / \mathrm{m}^{2}$, respectively, in the $\mathrm{BG}$ control. There were no differences in the number of weeds between PE mulch and the BG control from May to Aug. 2018 after the grower treated weeds with herbicides and handweeded the plots. However, number of weeds in the BG control was 266 weeds $/ \mathrm{m}^{2}$ and there were still no weeds in PE mulch plots in Sept. 2018 $(P=0.01)$. Weed dry shoot biomass in BG control was $1.6 \mathrm{~g} / \mathrm{m}^{2}$ for the same date. In contrast, in July 2019, number of weeds and dry shoot biomass were higher in the plots treated with PE mulch ( 13 weeds $/ \mathrm{m}^{2}$ and 0.03 $\mathrm{g} / \mathrm{m}^{2}$, respectively) compared with no weeds observed in BG control plots $(P=0.01$ for both). The most predominant weed species was common chickweed (Stellaria media L.).

\section{Discussion}

This study demonstrated that the specific thicknesses and formulations of BDMs evaluated in this study did not successfully overwinter in a late summer floricane-fruiting raspberry planting. Previous research with similar BDM products in a spring-planted floricane-fruiting raspberry field did not experience damage as extensive as what was observed in this study (Zhang et al., 2019). This could be because of longer primocanes in the first year of the spring-planted raspberry study resting on the mulches, thereby keeping the mulches in place and protecting them from wind damage. In the current study, tears, rips, and holes 2 months after application were the primary reasons that PSE increased in the BDM treatments, which was consistent with a tomato (Solanum lycopersicum L.) field study planted with BDMs 
Table 6. Yield of 'WakeHaven' raspberry planted in late summer in 2017 with polyethylene (PE) mulch and bare ground (BG). Harvest data were collected from all 15 harvest points from 28 June to 6 Aug. 2019.

\begin{tabular}{lllllcccccccccccc}
\hline & \multicolumn{10}{c}{ Yield $(\mathrm{kg} / 18 \mathrm{~m})$} \\
\hline Treatment & 1 & 2 & 3 & 4 & 5 & 6 & 7 & 8 & 9 & 10 & 11 & 12 & 13 & 14 & 15 & Total yield \\
\hline PE & $3.4 \mathrm{~b}^{\mathrm{z}}$ & 4.3 & 3.3 & 5.1 & 8.2 & $20.7 \mathrm{a}$ & 11.6 & 10.2 & 9.7 & 7.4 & 6.3 & 5.5 & 6.3 & 4.7 & 3.6 & 110.3 \\
BG & $9.5 \mathrm{a}$ & 8.5 & 4.7 & 6.8 & 10.6 & $17.0 \mathrm{~b}$ & 11.5 & 9.6 & 9.7 & 6.3 & 6.6 & 4.5 & 6.0 & 3.4 & 2.5 & 117.5 \\
$P$ value & 0.03 & 0.07 & 0.18 & 0.10 & 0.07 & 0.03 & 0.93 & 0.61 & 1.00 & 0.09 & 0.46 & 0.06 & 0.50 & 0.06 & 0.08 & 0.37 \\
\hline
\end{tabular}

${ }_{\mathrm{z}}$ Means followed by the same letter within a column are not significantly different at $P<0.05$ using a means comparison with a Tukey's honestly significant difference test.

(Miles et al., 2012). In the current study, damage at the edges of the mulches, primarily BDMs and one PE plot, occurred due to equipment from on-farm activities and were subsequently enlarged by 100 wind events with speed more than $36 \mathrm{~km} / \mathrm{h}$ from Oct. 2017 to Mar. 2018 (WSU AgWeatherNet, 2019). High winter winds are common for the production area where the study occurred because of cold air outflows from the Fraser River Valley in British Columbia.

The slightly lower breaking force and especially the smaller elongation (i.e., less elasticity) of BDMs indicate that these formulations and thicknesses were more susceptible to on-farm activities that can puncture the film and cause damage. Cowan et al. (2016) and Thompson et al. (2019) reported that bio-based plastic mulches have lower tensile strength and mechanical resistance compared with PE mulch. Dharmalingam et al. (2015) and Mendes et al. (2016) reported that tensile strength of plastic mulches is reduced when thermoplastic starch [e.g., polylactic acid (PLA)] is included. All BDMs used in this study contain bio-based materials (e.g., PLA and starch). These results suggest that BDMs may need to be reformulated to be more durable to withstand on-farm activities and winter conditions to be suitable for late summer plantings of floricane-fruiting raspberry where the mulch is exposed for several months (not covered with plant material). Alternatively, thicker BDMs may decrease the incidence and severity of damage observed in this study.

In contrast to the BDM treatments, PE mulch did overwinter, with the exception of one replicate that was ripped due to on-farm activities. More careful use of equipment would avoid such damage, and growers may need to adjust their farming practices to include plastic mulches. PE mulch provided weed suppression benefits relative to BG. Soil temperatures under PE mulch were similar to temperatures under BDMs and both were higher than the BG control, which is similar to what has been reported in other studies (DeVetter et al., 2017; Ghimire et al., 2018; Zhang et al., 2019) and may have contributed to increased primocane growth. Soil volumetric water content was generally higher in BDMs compared with PE mulch and the BG control. Northwest Washington has a Mediterranean climate characterized by dry summers and wet winters. There was $774 \mathrm{~mm}$ precipitation at the study site from Oct. 2017 to Mar. 2018 (WSU AgWeatherNet, 2019). Lower soil volumetric water content under PE mulch may be due to its impermeability that prevented rainfall from percolating into the soil. Bilck et al. (2010) reported BDMs made from PLA and polybutylene adipate terephthalate (PBAT) had up to 250 times higher water vapor permeability than PE mulch. The high permeability of BDMs likely allowed rainfall to move through the mulch, which raised soil volumetric water content relative to soil under $\mathrm{PE}$ mulch. The soil volumetric water content under Novamont mulches was higher than BASF mulches, which was consistent with our previous study (Zhang et al., 2019). Within each BDM product, thinner mulch (BASF 0.5 and Novamont 0.5 ) always had a higher soil volumetric water content than its corresponding thicker counterpart, and this was attributed to thickness impacting movement of water through the mulch material.

Both Trinka and Pritts (1992) and Zhang et al. (2019) reported plastic mulches increased primocane height in comparison with no-mulch treatments. Plants grown in BDMtreated plots had primocane heights similar to the BG plots, which was inconsistent with what has been observed in past studies (KrólDyrek and Siwek, 2015; Tecco et al., 2016; Zhang et al., 2019). This discrepancy was likely because of the early removal of BDMs (Mar. 2018) in the current study. In late summer planting systems, raspberry starts acclimating shortly after planting (Durner, 2013; Funt and Hall, 2013), and plant growth primarily occurs the following growing season (Apr. to Sept. 2018 in this study). Because BDMs were removed in Mar. 2018, plants grown in these plots during the 2018 growing season were under similar conditions to the plants grown in the BG control. Thus, plants had similar primocane heights across BDM treatments and the BG control in the study.

Raspberry primocane height was $6 \%$ to $8 \%$ greater among plants grown with $\mathrm{PE}$ mulch compared with the other treatments except for BASF 0.5 in Sept. 2018. Zhang et al. (2019) also observed primocane height of spring-planted TC raspberry grown with $\mathrm{PE}$ mulch to be $25 \%$ higher than the $\mathrm{BG}$ control. In the same study, it was also reported that spring-planted raspberry plants grown with $\mathrm{PE}$ mulch and BDMs had a higher primocane number (11-14 primocanes/plant) by the end of the first growing season compared with the BG control (7 primocanes/plant), which was not observed in the current study. The longer establishment period (18-24 months) for the late summer planting systems compared with the spring planting systems (4- to 6-month) may pro- vide adequate growing conditions and time for raspberry plants to establish and develop the maximum potential primocane height and number regardless of mulching.

Reducing the early flush of primocanes could reduce the need for chemically or physically removing primocanes through "burning" or "cutting," which may in turn increase on-farm efficiency and profitability. Early-growing primocanes are chemically or physically removed because they compete with developing flowers and fruit for nutrient and water resources (Crandall and Adams, 2020; DeVetter et al., 2020; Howard et al., 1989). PE mulch suppressed primocane emergence compared with the BG control in Spring 2019 (early emerged primocanes were chemically burned on 8 Apr. 2019 and 10 May 2019 by growers); however, we did not observe any differences in primocane number per plant in Sept. 2019. Thus, the concern that PE mulch could physically interfere with primocane emergence and reduce primocane number into the next year was not supported in our study. Instead, the suppressed primocane emergence observed early in the season under PE mulch may have allowed more photosynthates and mobile nutrients to be conserved and translocated to support fruit production and the formation of more desirable primocanes emerging from the crown region.

PE mulch application did not increase overall yield as reported in a previous study with spring-planted floricane-fruiting raspberry (Zhang et al., 2019). Winter injury among plants grown with PE mulch may be a contributing factor to the observed delay in fruit production and the lack of a yield effect observed in this study. Sønsteby and Heide (2014) reported that 'Glen Ample' raspberry (floricane-fruiting) had $71 \%$ budbreak after storage at $10{ }^{\circ} \mathrm{C}$ for $1175 \mathrm{~h}$. Funt and Hall (2013) described that floricane-fruiting raspberries grown across the world require 800 to 1600 chilling hours with a base temperature of $7.2{ }^{\circ} \mathrm{C}$. From 1 Oct. to 31 Dec. 2018, plants in this study accumulated $\approx 1077$ chilling hours (assuming a base temperature of $7.2{ }^{\circ} \mathrm{C}$ ) (WSU AgWeatherNet, 2019). Williams (1960) showed that 'Malling Promise' raspberry (floricane-fruiting) kept at $3.3^{\circ} \mathrm{C}$ in the greenhouse for $1008 \mathrm{~h}$ followed by exposure to $10{ }^{\circ} \mathrm{C}$ for 1 week induced raspberry budbreak. In our study, there were $16 \mathrm{~d}$ with maximum air temperatures over $10^{\circ} \mathrm{C}$ in Jan. 2019 followed by $10 \mathrm{~d}$ with minimum air temperatures below $-5{ }^{\circ} \mathrm{C}$ before mid-Feb. 2019 (WSU AgWeatherNet, 2019). Although the chilling requirement for the cultivar 
included in this study is not known, these environmental data and past studies suggest that the plants may have met their chilling requirements before Jan. 2019, and warmer temperatures in Jan. 2019 could have enabled plants to deacclimate. This effect and the onset of deacclimation may have been greater for raspberry plants grown with PE mulch given the higher soil temperatures. Visual observations made in Jan. 2019 indicated that plants grown with PE mulch had more swollen and expanded buds compared with plants in the BG control. Subsequent Feb. 2019 temperatures below $-5{ }^{\circ} \mathrm{C}$ may have therefore been more damaging to the primary buds of raspberry grown with PE mulch. As a result, secondary buds developed, but yield was lower and delayed. Warmund and George (1990) showed that cold injury on raspberry primary buds led to delayed flowering and fruiting.

In addition, frequent machine harvests at 2.5-day intervals on average could be another factor that led to a lack of an observable yield effect of raspberry grown with PE mulch. Plastic mulches have been demonstrated to hasten fruit maturity (Lalitha et al., 2010; Miles et al., 2012; Zhang et al., 2019), which was opposite to what was observed in the current study. Because of delayed fruit development, more flowers were visually observed on plants grown with $\mathrm{PE}$ mulch compared with the BG control during the first several harvests. Over-the-row machine harvesters harvest fruit through shaking and vibrations of harvester rods, which when done frequently could potentially knock off more flowers from the plants, thereby reducing the yield of plants grown with PE mulch.

Competition from weeds for nutrients, water, and space may hinder the establishment of TC raspberry plants (Lawson and Wiseman, 1974). Both PE mulch and BDMs suppressed weeds when mulches were present. Although growers handweeded in Dec. 2017 and May 2018 and applied herbicide (Simazine; Winfield United, Puyallup, WA) in BG plots, PE mulch successfully suppressed weeds compared with the BG control. The suppression of weed populations could be a contributing factor for increased raspberry primocane growth compared with the BG control.

\section{Conclusions}

Overall, PE mulch increased plant growth and both PE mulch and BDMs increased soil temperature while suppressing weeds compared with the BG control in floricane-fruiting raspberry established as TC transplants in late summer. Although plants grown with $\mathrm{PE}$ mulch produced the same yield as plants grown with the BG control, fruit size and quality tended to be greater when PE mulch was used. Primocane growth was also increased with mulch application. Therefore, $\mathrm{PE}$ mulch can be a viable management tool for raspberry growers practicing late summer plantings. Based on this study, the suitability of BDMs is unknown due to the damage caused by traditional on-farm activities and strong winds. Different formulations, thicker mulch materials, and more careful in-field management practices could reduce the risks associated with BDM durability for this planting time and system. Further studies are needed to explore the suitability of BDMs in floricane-fruiting raspberry in late summer plantings. Although there was no yield enhancement when PE mulch was used in our study, raspberry growers in the PNW are currently planting new fields in late summer with PE mulch due to other perceived benefits, such as weed management and modified soil conditions. In years without extremely cold weather that potentially can be more damaging to primary buds in plants treated with $\mathrm{PE}$ mulch, the yield might be higher among plants grown with $\mathrm{PE}$ mulch than $\mathrm{BG}$.

\section{Literature Cited}

American Society for Testing and Materials (ASTM). 2006. Standard test method for breaking strength and elongation of textile fabrics (strip method). ASTM D5035-06. ASTM International, West Conshohocken, PA.

Anzalone, A., A. Cirujeda, J. Aibar, G. Pardo, and C. Zaragoza. 2010. Effect of biodegradable mulch materials on weed control in processing tomatoes. Weed Technol. 24:369-377.

ASTM. 2018. Standard test method for determining aerobic biodegradation of plastic materials in soil. ASTM D5988-18. ASTM International, West Conshohocken, PA.

Bilck, A.P., M.V. Grossmann, and F. Yamashita. 2010. Biodegradable mulch films for strawberry production. Polym. Test. 29:471-476.

Brodhagen, M., M. Peyron, C. Miles, and D.A Inglis. 2015. Biodegradable plastic agricultural mulches and key features of microbial degradation. Appl. Microbiol. Biotechnol. 99:10391056.

Costa, R., A. Saraiva, L. Carvalho, and E. Duarte. 2014. The use of biodegradable mulch films on strawberry crop in Portugal. Scientia Hort. 173:65-70.

Cowan, J.S., D.A. Inglis, and C.A. Miles. 2013. Deterioration of three potentially biodegradable plastic mulches before and after soil incorporation in broccoli field production system in northwestern Washington. HortTechnology 23:849-858

Cowan, J.S., A.M. Saxton, K.K. Leonas, D. Inglis, and C.A. Miles. 2016. Visual assessments of biodegradable mulch deterioration are not indicative of changes in mechanical properties. HortScience 51:245-254.

Crandall, P.C. and E.B. Adams. 2020. Primocane pruning to increase red raspberry production. Washington State Univ. Ext. Publ. EM 4398. 17 Aug. 2019. <https://research.wsulibs.wsu.edu:8443/xmlui/bitstream/handle/2376/16166/ em4398_1979.pdf? sequence=1\&isAllowed=y $>$.

DeVetter, L.W., B.C. Strik, P. Moore, C. Finn, M. Dossett, R. Sagili, T. Miller, C. Benedict, D.R. Bryla, I. Zasada, B. Martin, J. Pscheidt, J.E. Weiland, T. Peever, L. Tanigoshi, B. Gerdeman, J. DeFrancesco, J. Lee, S. Korthuis, and Y. Zhao. 2020. Commercial red raspberry production in the Pacific Northwest. Washington State Univ. Ext. Publ. PNW598.

DeVetter, L.W., H. Zhang, S. Ghimire, S. Watkinson, and C.A. Miles. 2017. Plastic biodegradable mulches reduce weeds and promote crop growth in day-neutral strawberry in western Washington. HortScience 52:1700-1706.
Dharmalingam, S., D.G. Hayes, L.C. Wadsworth, R.N. Dunlap, J.M. DeBruyn, J. Lee, and A.L. Wszelaki. 2015. Soil degradation of polylactic acid/polyhydroxyalkanoate-based nonwoven mulches. J. Polym. Environ. 23:302-315.

Durner, E.F. 2013. Principles of horticultural physiology. CABI, Oxfordshire, UK.

European Norms (EN). 2018. Plastics - biodegradable mulch films for use in agriculture and horticulture requirements and test methods. EN 17033. European Standard, European Committee for Standardization, Brussels, Belgium.

Funt, R.C. and H.K. Hall. 2013. Raspberries. CABI, Oxfordshire, UK.

Ghimire, S., A.L. Wszelaki, J.C. Moore, D.A. Inglis, and C. Miles. 2018. The use of biodegradable mulches in pie pumpkin crop production in two diverse climates. HortScience 53:288-294.

Goldberger, J.R., R.E. Jones, C.A. Miles, R.W Wallace, and D.A. Inglis. 2015. Barriers and bridges to the adoption of biodegradable plastic mulches for US specialty crop production. Renew. Agr. Food Syst. 30:143-153.

Grossman, E. 2019. How can agriculture solve its $\$ 5.87$ billion plastic problem? 17 June 2019. <https://www.greenbiz.com/article/howcan-agriculture-solve-its-1-billion-plasticproblem>.

Howard, S.W., C.B. MacConnell, and J.S. Cameron. 1989. Evaluation of cane burning materials for red raspberry. Proc. Act. Hort. 262:365-372.

Kasirajan, S. and M. Ngouajio. 2012. Polyethylene and biodegradable mulches for agricultural applications: A review. Agron. Sustain. Dev. 32:501-529.

Król-Dyrek, K. and P. Siwek. 2015. The influence of biodegradable mulches on the yielding of autumn raspberry (Rubus idaeus L.). Folia Hort. 27:15-20.

Lalitha, M., V.K. Thilagam, N. Balakrishnan, and M. Mansour. 2010. Effect of plastic mulch on soil properties and crop growth - A review. Agr. Rev. 31:145-149.

Lamont, W.J. 2017. Plastic mulches for the production of vegetable crops, p. 45-60. In: M. Orzolek (ed.). A guide to the manufacture, performance, and potential of plastics in agriculture. Elsevier, Oxford, UK.

Lawson, H.M. and J.S. Wiseman. 1974. Effect of weeds and herbicides in young raspberry plantations. Proc. Br. Weed Cont. Conf. 12:683690.

Levitan, L. and A. Barros. 2019. Recycling agricultural plastics in New York State. Environmental Risk Analysis Program. Cornell Univ., Ithaca, NY. 17 June 2019. <http://cwmi.css.cornell.edu/recyclingagplastics.pdf/>.

Mendes, J.F., R. Paschoalin, V.B. Carmona, A.R. Sena Neto, A.C.P. Marques, J.M. Marconcini, L.H.C. Mattoso, E.S. Medeiros, and J.E. Oliveira. 2016. Biodegradable polymer blends based on corn starch and thermoplastic chitosan processed by extrusion. Carbohydr. Polym. 137:452-458.

Miles, C., L. DeVetter, S. Ghimire, and D.G. Hayes. 2017. Suitability of biodegradable plastic mulches for organic and sustainable agricultural production systems. HortScience 52:10-15.

Miles, C., R. Wallace, A. Wszelaki, J. Martin, J. Cowan, T. Walters, and D. Inglis. 2012. Deterioration of potentially biodegradable alternatives to black plastic mulch in three tomato production regions. HortScience 47:12701277. 
Peerbolt, T. 2020. 2019 raspberry plant sales. 28 Jan. 2020. <https://drive.google.com/file/d/ 1cDUe8klVwSoBA8uheu_1kDMGh0pU8ATR/ view>.

Sønsteby, A. and O.M. Heide. 2014. Cold tolerance and chilling requirements for breaking of bud dormancy in plants and severed shoots of raspberry (Rubus idaeus L.). J. Hort. Sci. Biotechnol. 89:631-638.

Tecco, N., C. Baudino, V. Girgenti, and C. Peano. 2016. Innovation strategies in a fruit growers association impacts assessment by using combined LCA and s-LCA methodologies. Sci. Total Environ. 568:253-262.

Theiler-Hedtrich, R. and G. Baumann. 1989. Elimination of apple mosaic virus and raspberry bushy dwarf virus from infected red raspberry (Rubus ideaus L.) by tissue culture. J. Phytopathol. 127:193-199.

Thompson, A.A., M.B. Samuelson, I. Kadoma, E. Soto-Cantu, R. Drijber, and S.E. Wortman.
2019. Degradation rate of bio-based agricultural mulch is influenced by mulch composition and biostimulant application. J. Polym. Environ. 27:498-509.

Trinka, D.L. and M.P. Pritts. 1992. Micropropagated raspberry plant establishment responds to weed control practice, row cover use, and fertilizer placement. J. Amer. Soc. Hort. Sci. 117:874-880.

USDA NASS. 2019. USDA Non-citrus Fruits and Nuts 2018 Summary. 21 Aug. 2019. <https:// www.nass.usda.gov/Publications/Todays_Reports/ reports/ncit0619.pdf>.

USDA. 2019. Web Soil Survey. 17 June 2019. $<$ https://websoilsurvey.sc.egov.usda.gov/>.

Velandia, M., A. Smith, A. Wszelaki, and S. Galinato. 2019. The Economic Feasibility of Adopting Plastic Biodegradable Mulches in Pumpkin Production. Univ. of Tennessee Ext. Publ. W 822. 21 Aug. 2019. <https://exten-
sion.tennessee.edu/publications/Documents/ W822.pdf>.

Warmund, M.R. and M.F. George. 1990. Freezing survival and supercooling in primary and secondary buds of Rubus spp. Can. J. Plant Sci. 70:893-904.

Washington State University (WSU) AgWeatherNet. 2019. Washington State Univ. AgWeatherNet, Mount Vernon, WA. 29 June 2019. $<$ http://weather.wsu.edu/ $>$.

Williams, I.H. 1960. Effects of environment on Rubus idaeus L.V. dormancy and flowering of the mature shoot. J. Hort. Sci. 35:214-220.

Zhang, H., C. Miles, S. Ghimire, C. Benedict, I. Zasada, and L. DeVetter. 2019. Polyethylene and biodegradable plastic mulches improve growth, yield, and weed management in floricane red raspberry. Scientia Hort. 250:371379. 